\title{
GENOME CHANGES IN THE TOXOPLASMA GONDII STRAINS DURING LABORATORY PASSAGES IN MICE
}

\author{
I. LITERÁK ${ }^{1}$ and I. RYCHLÍK ${ }^{2}$ \\ ${ }^{1}$ Faculty of Veterinary Medicine, University of Veterinary and Pharmaceutical Sciences, \\ ${ }^{2}$ Veterinary Research Institute, Brno, Czech Republic \\ Received April 12, 1999 \\ Accepted July 16, 1999
}

Abstract

Literák I., I. Rychlík: Genome Changes in the Toxoplasma gondii Strains During Laboratory Passages in Mice. Acta Vet. Brno 1999, 68: 203-208.

Three strains of Toxoplasma gondii isolated from rabbits (K6 and K9) and a cat (K24) in the Czech Republic in 1994-95 were maintained in a tissue cyst form in laboratory mice by injections of brain homogenate every $4-6$ months. These strains were passaged 12 to 13 times before tachyzoites, from which DNA was isolated, were obtained. PCR/RFLP (restriction fragment length polymorphism) (ROP1 gene/DdeI restriction endonuclease) and RFLP/DNA (RFLP with chromosomal DNA) (TGR1E probe/PstI and SalI restriction endonucleases) were used to characterize their genotypes. In the course of subsequent tissue cyst-tissue cyst passages, the pathogenicity of the strains increased and intraperitoneal passaging of tachyzoites from the peritoneal exudate two times weekly had to be used to facilitate the continuous maintenance. After the pathogenicity increase, the DNA was isolated from the tachyzoites after 6 to 48 tachyzoite-tachyzoite passages. Genotype differences were observed in the strain before and after increasing their pathogenicity. Both PCR/RFLP and RFLP/DNA patterns of the strain before and after increasing their pathogenicity were similar, and even identical, with previously described genotype characteristics of avirulent and virulent strains of $T$. gondii.

Toxoplasma gondii, PCR/RFLP, RFLP/DNA, DNA fingerprinting, strains, pathogenicity, virulence

Toxoplasma gondii is a protozoan parasite of mammals and birds with worldwide occurrence (Dubey and Beattie 1988). In man and in sensitive animal species, it may be the cause of asymptomatic as well as lethal infections. In view of different manifestations of toxoplasmosis in the same host species, pathogenicity of individual strains of $T$. gondii has been studied to explain different manifestations of the disease by different pathogenicity of strains. Sibley and Boothroyd (1992) stated that "virulent" relates to strains with $\mathrm{LD}_{100}(100 \%$ lethal dose $)<10$ tachyzoites for outbred Swiss mice, and "non-virulent" (avirulent) to strains with $\mathrm{LD}_{100}>10^{3}$ tachyzoites.

Genotype studies of individual $T$. gondii strains based on restriction fragment length polymorphism of the chromosomal DNA (RFLP/DNA) and RFLP of a specific DNA sequence amplified by the PCR (PCR/RFLP) fitted closely with the $T$. gondii pathogenicity. Those studies documented the characteristic genotypes of virulent and avirulent strains (Cristina et al. 1991ab; Sibley and Boothroyd 1992; Cristina et al. 1995; Howe and Sibley 1994, 1995; Literák et al. 1998).

Most $T$. gondii strains have been isolated by means of passages in laboratory mice. Laboratory mice have also been used to maintain a number of strains on a long-term basis, and many different types of strain analyses, including genotype analysis, have been performed after the strains have been multiplied in laboratory mice. An interesting phenomenon has been observed in some strains for several decades: their pathogenicity

Address for correspondence:

Doc. MVDr. Ivan Literák, CSc.
Department of Infectious Diseases and Veterinary Epidemiology,

Faculty of Veterinary Medicine, University of Veterinary and Pharmaceutical Sciences

Palackého 1-3, 61242 Brno, Czech Republic

Phone: ++420-5-41 562307

Fax: ++420-5-74 8841

http://www.vfu.cz/acta-vet/actavet.htm 
increased after parenteral passages on laboratory mice (De Rodaniche 1954; Jacobs and Melton 1954; Jacobs 1956; Rašín 1970). Increase in pathogenicity was also observed in the RH strain after it was isolated in 1939 (Sabin 1941), which is at present considered as a model of virulent strains.

Virulent strains are maintained in laboratories by repeated i.p. passages of tachyzoites in laboratory mice, where $\mathrm{LD}_{100}$ may be 1 tachyzoite only. Tachyzoites of those strains convert to bradyzoites in mice only if the mice had been treated sulfadiazine (Frenkel et al. 1976; Dardé et al. 1992). The cats fed with tissue cysts containing such bradyzoites do not excrete oocysts if the tachyzoites of virulent strains have undergone more than 35 i.p. passages in mice (Frenkel et al. 1976) or the capacity of oocyst production was absent even for some other virulent strains studied less than ten passages after their isolation in mice (Dardé et al. 1992).

In our laboratory, strains of $T$. gondii are maintained in mice. In some strains, a marked increase in pathogenicity was observed during subsequent passages and to maintain the strains, passaging tachyzoites at 3 to 4 day intervals had to be used instead of previously performed bradyzoite (tissue cyst) passages at $4-6$ month intervals. In three such strains, we tested the genotype characteristics (RFLP/DNA, PCR/RFLP) both before and after their pathogenicity increased and we found that the same strains had clearly different genotypes before and after their pathogenicity increased. This paper is a description of the changes observed and their tentative explanation.

T. gondii strains (Table 1)

\section{Material and Methods}

Table 1

Toxoplasma gondii strains used in the study

\begin{tabular}{|l|c|c|c|c|c|}
\hline Strain & K6 & K19 & K24 & K25 & Z92 \\
\hline Host & Rabbit & Rabbit & Cat & Cat & Wild cat \\
\hline Stage in time of isolation & Tissue cyst & Tissue cyst & Oocyst & Oocyst & Oocyst \\
\hline $\begin{array}{l}\text { Year } \\
\text { of isolation }\end{array}$ & 1995 & 1994 & 1995 & 1995 & 1995 \\
\hline $\begin{array}{l}\text { No. of passages } \\
\text { in mice }\end{array}$ & 13 & 13 & 12 & 7 & 6 \\
\hline $\begin{array}{l}\text { No. of passages } \\
\text { in mice } \\
\text { (not counted) }\end{array}$ & 8 and 14 & 5 & 48 and 48 & Not done & Dozens \\
\hline $\begin{array}{l}\text { No. of passages } \\
\text { in mice }\end{array}$ & 6 & Not done & Not done \\
\hline
\end{tabular}

a passages of tissue cysts from the time of strain isolation to the time of obtaining tachyzoites after maintenance of mice with hydrocortisone and the first DNA extraction

b passages of tachyzoites from the time of increasing the pathogenicity to the time of DNA extraction

$c$ passages of tachyzoites from the time of increasing the pathogenicity to the time of testing the pathogenicity

The strains used in the study included K6, K19, K24, K25 and Z92 strains isolated in the Czech Republic in 1994 and 1995 (Literák et al. 1998). Strains were maintained in a tissue cyst form in mice by injections of brain homogenate every 4-6 months. The first batch of tachyzoites of these strains were obtained by a modification of the process described by Dardé et al. (1992). Tachyzoites were obtained by inoculating T. gondii cysts i.p. into mice previously treated by s.c. injections of hydrocortisone sodium succinate at $40 \mathrm{mg} / \mathrm{kg}$ every two days for 20 days. Hydrocortisone injections were continued after the inoculation with brain cysts, and tachyzoites were harvested from the ascitic fluid between 8 and 10 days after inoculation. Tachyzoites were multiplied on VERO cells and concentrated by centrifugation after the so-called forced extrusion through a $22 \mathrm{G}$ needle. In subsequent passages using brain homogenate containing tissue cysts, all the K6, K19 and K24 strains with the exception of K25 strain increased their pathogenicity. Mice infected with 
an estimated standard dose of brain suspension died within a month after infection, and in order to maintain the K6, K19, K24 a Z92 strains, i.p. passages of tachyzoites in mice 2 times weekly had to be used.

Specific pathogen-free mice of the CD1 outbred strain were used for the isolation and passages of $T$. gondii strains.

For each strain, tachyzoites obtained from VERO cells or ascitic fluid of mice were washed three times $(950 \mathrm{~g}$ for $10 \mathrm{~min}$ ) in PBS and stored at $-18^{\circ} \mathrm{C}$.

\section{DNA Extraction, PCR/RFLP and RFLP/DNA}

DNA was isolated from tachyzoite suspension ( $200 \mu \mathrm{PBS}, 10^{7}$ tachyzoites) using QIAamp Tissue Kit (Qiagen, Hilden, Germany) according to manufacturer's instructions. PCR/RFLP: The target DNA for PCR amplification was the published sequence of the ROP1 locus (Ossorio et al. 1992). Amplification was performed with Taq PCR Master Mix Kit (Qiagen) in a final volume of $40 \mathrm{ml}$ with the primers 5'-CGTGACATATACTGCACTGAC and 5'- CATCTGCAAACTCGATCAC (nucleotides 170-191 and 1489-1508, respectively) (Howe and Sibley 1994). Samples were amplified for 40 cycles as follows: $30 \mathrm{~s}$ of denaturation at $94{ }^{\circ} \mathrm{C}, 1$ min of annealing at $64{ }^{\circ} \mathrm{C}$ and 2 min of extension at $72{ }^{\circ} \mathrm{C}$. The amplification products were digested with $D d e$ I restriction endonuclease (New England Biolabs) (Howe and Sibley 1994) and separated by electrophoresis in $1.5 \%$ agarose gel. The results were visualized by ethidium bromide staining.

RFLP/DNA was performed as described previously (Literák et al., 1998). Isolated DNA was digested with restriction endonuclease PstI and SalI (Amersham, UK). After electrophoresis in agarose gel, restriction fragments were vacuum blotted onto nylon membrane (Hybond N, Amersham, UK). The probe was prepared by PCR, which amplified selected region of repetitive sequence TGR1E (Cristina et al., 1991). Sequences of primers were forward: 5'-GGAGATGGTCGGGCGTATTG, reverse: 5'- CACCTGTGCCGCAAATGAAA. Probe was labelled with 32P adATP by Random Primed Labelling kit (Amersham, UK). After hybridization, membranes were washed, dried and exposed (Literák et al. 1998).

\section{T. gondii pathogenicity}

Pathogenicity of the $T$. gondii strains during tachyzoite-tachyzoite mouse passages was tested. CD1 mice weighing $20 \pm 2$ g were injected i.p. with 1 to 104 tachyzoites of K6, K19 and K24 strains obtained from mouse peritoneal fluid. Each dose was injected to 4 to 5 mice. Mouse mortality was monitored for 30 days p.i. On Day 30 p.i., surviving mice were tested for seroconversion and the presence of tissue cysts in the brain. Serological examination was performed using the latex agglutination test (Sanofi Pasteur, France), with serum at dilution of 1:10.

Table 2

Pathogenicity of $T$. gondii strains during tachyzoite-tachyzoite mouse passages

\begin{tabular}{|l|c|c|c|c|}
\hline $\begin{array}{l}\text { Infection Dose } \\
\text { Strain (No.of Passage) }\end{array}$ & 1 & 10 & 100 & 1000 \\
\hline K6 (8) & $\begin{array}{c}5^{\mathrm{a} / 5^{\mathrm{b}}} \\
9^{\mathrm{c}}, 9,9,10,10\end{array}$ & $\begin{array}{c}5 / 5 \\
9,9,9,9,9\end{array}$ & $\begin{array}{c}5 / 5 \\
8,8,8,9,9\end{array}$ & $\begin{array}{c}5 / 5 \\
\leq 7, \leq 7,8,8,9\end{array}$ \\
\hline K6 (14) & $4 / 4$ & $4 / 4$ & $4 / 4$ & $4 / 4$ \\
& $11,12,12,12$ & $12,12,12,13$ & $11,11,12,12$ & $11,11,12,12$ \\
\hline K19(5) & $4 / 4$ & $4 / 4$ & $4 / 4$ & $4 / 4$ \\
& $12,12,12,14$ & $9,9,9,13$ & $11,12,12,12$ & $10,11,11,11$ \\
\hline K24 (45) & $3^{\mathrm{d} / 4}$ & $4 / 4$ & $4 / 4$ & $4 / 4$ \\
& $12,12,13$ & $12,12,12,13$ & $11,11,11,12$ & $11,11,11,12$ \\
\hline
\end{tabular}

a number of dead mice

b number of mice infected

c number of days from infection to death

d One of the 4 mice survived until Day 30 p.i.. A serological examination of that mouse did not demonstrate any antibodies against toxoplasmosis (LAT), i.e. the mouse was not infected.

\section{Results}

PCR/RFLP results are shown in Fig. 1. PCR digest profiles in K6, K19 and K24 strains were different if the DNA was isolated before and after an increase in their pathogenicity. In the K25 strain, no increase in pathogenicity was recorded, and its PCR/RFLP profile was 
identical with that of K6, K19 and K24 strains before the increase in pathogenicity. The PCR/RFLP profile of the virulent Z92 strain was identical with the profile of K6, K19 and K24 strains after the increase in pathogenicity.

RFLP/DNA results before and after the increase in strain pathogenicity were also different. The DNA fingerprint of the K25 strain was similar to those of K6, K19 and K24 strains before their pathogenicity increased. The DNA fingerprint of the Z92 strain was similar to those of K6, K19 and K24 strains after the pathogenicity increase.

K6, K19 and K24 strains increased their pathogenicity with subsequent passages of tissue cysts and their pathogenicity was accurately determined during their subsequent tachyzoite-tachyzoite i.p. passages every 3 to 4 days. These strains exhibited high pathogenicity (Table 2). Between passage 5 to 45 , a single tachyzoite of those strains was able to kill the infected CD1 mouse in 9-14 days p.i. At the time of their isolation and 13 (K6 and K19) and 12 (K24) tissue cyst - tissue cysts i.p. passages once every 4 to 6 months, the same strains exhibited much lower pathogenicity and the mice infected with them did not usually die.

\section{Discussion}

A comparison of genotype characteristics between two phases of the K6, K19 and K24 strains revealed unexpected differences that exactly matched the differences recorded in earlier DNA typing of "avirulent" and "virulent" strains of T. gondii (Cristina et al. 1991ab; Howe and Sibley 1994; Cristina et al. 1995; Literák et al. 1998). Howe and Sibley (1994) used PCR/RFLP (ROPI/DdeI) to characterize the differences between avirulent and virulent strains. Their PCR profiles of avirulent and virulent strains were identical with PCR profiles of our strains in their avirulent and virulent phases, respectively. Using RFLP and the TGR1E probe, significant differences between DNA fingerprints of avirulent and virulent strains of $T$. gondii were observed (Cristina et al. 1991ab, 1995; Literák et al. 1998). Very similar differences between DNA fingerprints were also found in our strains between their avirulent and virulent phases.

Based on these findings, we hypothesize that the increase in pathogenicity of $T$. gondii strains is related to mutations in their genome. Some authors have assumed mutation changes in T. gondii strains (Frenkel et al. 1976; Frenkel and Ambroise-Thomas 1997) and Jacobs (1956) suggested that the mouse pathogenicity of $T$. gondii strains can be manipulated in the laboratory. Frenkel et al. (1976) concluded from their experiments that after routine mouse passages of $T$. gondii tachyzoites, an important genomic change can occur, because the oocyst-forming capacity of tissues cysts from such tachyzoites was lost in 2 experiments. Frenkel and Ambroise-Thomas (1997) then reviewed studies concerning the genomic polymorphism of $T$. gondii and concluded that after prolonged multiplication exclusively in the tachyzoite stage in mice, and possibly also in toxoplasmosis patients, the gametocyte-forming ability may be lost, and that selection of some mutations by the host animal or growth system was evident.

Genotype characterization of $T$. gondii strains not isolated from clinical material or later passaged in laboratory mice are very rare. The diagnostic PCR derived from the betatubuline gene not only allows the detection of $T$. gondii DNA but also to differentiate between virulent and avirulent strains (Costa et al. 1997). This method has been used to test 37 samples of amniotic fluid from infected human foetuses. All of the 37 T. gondii DNAs had (TG)7 microsatellite marker indicating that these cases of congenital toxoplasmosis were due to strains from for mice "avirulent" $T$. gondii lineage even if their pathogenicity in human foetuses was evident, as numerous abnormalities were observed on ultrasound examination. The results support our hypothesis that the virulent genotype could be a result of mutation of the $T$. gondii strains passaged repeatedly and atypically in laboratory mice. 
In the light of our hypothesis, it is therefore not surprising that none of 43 strains isolated from pigs in the USA and passed no more than twice in mice (Mondragon et al. 1998) were categorized as having an acutely virulent phenotype by the genotype PCR/RFLP characterization.

How genome changes affect pathogenicity remains to be elucidated.

\section{Změny genomu u kmenů Toxoplasma gondii v průběhu pasážování na laboratorních myších}

Třri kmeny Toxoplasma gondii izolované v České republice v letech 1994-1995 z králíků (K6 a K9) a z kočky (K24) byly udržovány ve formě tkáňových cyst u laboratorních myší pasážováním mozkového homogenátu co 4-6 měsíců. Kmeny byly pasážovány 12-13 krát, než z nich byly získány tachyzoity, ze kterých byla izolována DNA k charakterizaci jejich genotypu. K této charakterizaci byla použita restrikční analýza specifického produktu polymerázové řetězové reakce (PCR/RFLP) (gen ROP1, restrikční endonukleáza DdeI) a restrikční analýza chromozomální DNA (RFLP/DNA) (sonda TGR1E, restrikční endonukleázy PstI a SalI). V průběhu následných pasáží tkáňových cyst se virulence (patogenita) kmenů K6, K9 a K24 zvýšila a k tomu, aby bylo možné tyto kmeny dále udržet $\mathrm{v}$ laboratoři, bylo nutné přistoupit $\mathrm{k}$ opakovanému intraperitoneálnímu pasážování tachyzoitů v peritoneálním exsudátu v intervalu 2 krát týdně. Po zvýšení virulence byla DNA opět izolována z tachyzoitů po 6-48 pasážích u jednotlivých kmenů. Byly pozorovány změny genotypu u těchto kmenů před zvýšením a po zvýšení virulence. Genotypové charakteristiky (PCR/RFLP i RFLP/DNA) byly u kmenů před zvýšením i po zvýšení virulence podobné nebo dokonce identické s charakteristikami, které byly dř́ve popsány $\mathrm{u}$ avirulentních a virulentních kmenů $T$. gondii.

\section{Acknowledgements}

This study was funded by grant no. 524/98/0111 from the Grant Agency of the Czech Republic. We are grateful to Prof. J. K. Frenkel for his helpful comments on an earlier draft of the paper.

\section{References}

COSTA, J. M., DARDÉ, M.-L., ASSOULINE, B., VIDAUD, M., BRETAGNE, S. 1997: Microsatellite in the betatubulin gene of Toxoplasma gondii as a new genetic marker for use in direct screening of amniotic fluids. J. Clin. Microbiol. 35: 2542-2545

CRISTINA, N., OURY, B., AMBROISE-THOMAS, P., SANTORO, F. 1991b: Restriction-fragment-length polymorphisms among Toxoplasma gondii strains. Parasitol. Res. 77: 266-268

CRISTINA, N., LIAUD, M.-F., SANTORO, F., OURY, B., AMBROISE-THOMAS, P. 1991a: A family of repeated DNA sequences in Toxoplasma gondii: cloning, sequence analysis, and use in strain characterization. Exp. Parasitol. 73: 73-81

CRISTINA, N., DARDÉ, M. L. BOUDIN, C., TAVERNIER, G., PESTRE-ALEXANDRE, M., AMBROISE- THOMAS, P. 1995: A DNA fingerprinting method for individual characterization of Toxoplasma gondii strains: combination with isoenzymatic characters for determination of linkage groups. Parasitol. Res. 81: 32-37

DARDÉ, M. L., BOUTEILLE, B., PESTRE-ALEXANDRE, M. 1992: Isoenzyme analysis of 35 Toxoplasma gondii isolates and the biological and epidemiological implications. J. Parasitol. 78: 786-794

DE RODANICHE, E. 1954: Spontaneous toxoplasmosis in the white face monkey, Cebus capucinus in Panama. Am. J. Trop. Med. Hyg. 3: 1023-1025

DUBEY, J. P., BEATTIE, C. P. 1988: Toxoplasmosis of Animals and Man. CRC Press, Boca Raton, Florida.

FRENKEL, J. K., AMBROISE-THOMAS, P. 1997: Genomic drift of Toxoplasma gondii. Parasitol. Res. 83: 1-5

FRENKEL, J. K., DUBEY, J. P., HOFF, R. L. 1976: Loss of stages after continuous passage of Toxoplasma gondii and Besnoitia jellisoni. J. Protozool. 23: 421-424

HOWE, D. K., SIBLEY, L. D. 1994: Toxoplasma gondii: Analysis of different laboratory stocks of the RH strain reveals genetic heterogenity. Exp. Parasitol. 78: 242-245

HOWE, D. K., Sibley, L. D. 1995: Toxoplasma gondii comprises three clonal lineages: correlation of parasite genotype with human disease. J. Infect. Dis. 172: 1561-1566

JACOBS, L. 1956: Propagation, morphology, and biology of Toxoplasma. Ann. N. Y. Acad. Sc. 64: 154-179 
JACOBS, L., MELTON, M. L. 1954: Modification in pathogenicity of a strain of Toxoplasma gondii by passage in various hosts. Am. J. Trop. Med. Hyg. 3: 447-457

LITERÁK, I., RYCHLÍK, I., SVOBODOVÁ, V., POSPÍŠIL, Z. 1998: Restriction fragment length polymorphism and pathogenicity of Czech Toxoplasma gondii strains. Int. J. Parasitol. 28: 1367-1374

MONDRAGON, R., HOWE, D. K., DUBEY, J. P., SIBLEY, L. D. 1998: Genotypic analysis of Toxoplasma gondii isolates from pigs. J Parasitol. 84: 639-641

OSSORIO, P. N., SCHWARTZMEN, J. D., BOOTHRYOD, J. C. 1992: A Toxoplasma gondii rhoptry protein associated with host cell penetration has unusual charge asymetry. Mol. Biochem. Parasitol. 50: 1-16

RAŠÍN, K. 1970: Toxoplasma gondii Nicolle et Manceaux 1909: Strains isolated from hares (Lepus europaeus Pall.) (in Czech, English summary). Vet. Med. (Prague) 15: 127-145

SABIN, A. B. 1941: Toxoplasmic encephalitis in children. J. Am. Med. Assoc. 116: 801-807

SIBLEY, L. D., BOOTHROYD, J. C. 1992: Virulent strains of Toxoplasma gondii comprise a single clonal lineage. Nature 359: $82-85$ 